\title{
AKSES DAN KONTROL PEREMPUAN PETANI PENGGARAP PADA LAHAN PERTANIAN PTPN IX KEBUN MERBUH
}

\section{Asma Luthfi}

Jurusan Sosiologi dan Antropologi, Fakultas Ilmu Sosial, Universitas Negeri Semarang, Indonesia

\section{Info Artikel}

Sejarah Artikel:

Diterima Juni 2010

Disetujui Juli 2010

Dipublikasikan September 2010

Keywords:

Control;

Women;

Tenant Farmers.

\begin{abstract}
Abstrak
Peran perempuan pada bidang pertanian memiliki kontribusi yang cukup banyak, khususnya pada peningkatan ekonomi keluarga. Tetapi peran ini tidak diimbangi dengan kesempatan dan kewenangan mereka terhadap sumber-sumber pertanian serta fasilitas publik lainnya. Tulisan ini bertujuan untuk menjelaskan tentang akses dan kontrol perempuan petani penggarap pada lahan PTPN IX Kebun Merbuh. Metode yang digunakan dalam penelitian ini adalah metode penelitian kualitatif melalui observasi dan wawancara. Hasil penelitian menunjukkan bahwa akses dan kontrol perempuan petani penggarap pada lahan PTPN IX masih lemah jika dibandingkan dengan laki-laki, meski mereka memainkan banyak peran domestik dan publik. Kondisi ini membuat perempuan masih terpinggirkan dalam produski pertanian serta masih mengalami beban ganda dalam kehidupan mereka.
\end{abstract}

\section{Abstract}

The contribution of women in agriculture is significant, especially in the economy of the family. However, this important contribution is not matched by the equal opportunity and access to the agricultural resources and other public facilities. In this paper, I seek to explore women's access to and control of tenant farmers on the land PTPN IX Kebun Merbuh. The method used in this study is a qualitative method; data are collected through observation and interviews. The results show that women's access to and control of tenant farmers on the land PTPN IX is still weak, compared with men, though they play many important domestic and public roles. As a result, these women are still marginalized in agricultural production and are still experiencing double burden in their lives.

(C) 2010 Universitas Negeri Semarang 


\section{PENDAHULUAN}

Sebagai negara agraris, Pemerintah Indonesia masih menitikberatkan pembangunannya pada sektor pertanian. Sebagian besar penduduk Indonesia berada di wilayah pedesaan dan bekerja pada sektor pertanian. Program kebijakan pertanian yang dilakukan oleh Pemerintah Orde Baru memangtelahberhasilmencapaiswasembada pangan dengan program revolusi hijaunya. Tetapi keberhasilan itu harus dibayar mahal dan tidak membawa perbaikan riil pada tingkat kehidupan petani. Pasca Orde Baru, nasib petani tidak juga membaik akibat liberalisasi pertanian yang hanya menguntungkan pengusaha besar (Suseno dan Hempry Suyatna, 2007:271). Untuk itu, pemerintah menggalakkan pembangunan pertanian yang dimaksudkan sebagai strategi dan upaya untuk meningkatkan pendapatan petani, menciptakan lapangan kerja, mengentaskan kemiskinan, memantapkan ketahanan pangan, dan mendorong pertumbuhan ekonomi wilayah.

Gerakan pembangunan pertanian ini digalakkan secara masif di desadesa, bahkan terintegrasi dalam beberapa program pemerintah yang lain. Pada sektor perkebunan karet, khususnya di PTPN IX, pembangunan pertanian ini dapat dilihat pada Program Kemitraan Bina Lingkungan (PKBL). Program ini yang memberikan kesempatan kepada masyarakat untuk memanfaatkan lahan dengan menanam tanaman tumpang sari di sela-sela pohon karet yang belum menghasilkan getah. Sasaran utamanya adalah petani lokal yang tidak memiliki lahan, agar pendapatan dan kesejahteraan mereka dapat meningkat.

Bagi warga Meteseh, Kecamatan Boja, Kabupaten Kendal, pemanfaatan lahan karet PTPN IX ini memberikan kontribusi positif bagi peningkatan ekonomi rumah tangga mereka. Hampir semua warga yang tidak berlahan bisa memanfaatkan lahan tersebut secara maksimal. Dalam pengelolaannya pun melibatkan seluruh sumber daya yang ada dalam keluarganya, termasuk perempuan. Peran nyata perempuan dalam pengelolaan lahan ini sangat jelas terlihat, mulai dari tahap menanam, tahap memanen, hingga pada tahap distribusi produknya. Hanya saja, peran tersebut seringkali tidak dianggap sebagai faktor penentu keberhasilan pengelolaan lahan PTPN IX dan faktor utama peningkatan ekonomi keluarga. Hal ini karena peran mereka acapkali diabaikan dan kurang diakui secara ekonomi dan sosial.

Tulisan ini akan membicarakan tentang relasi gender dalam aktivitas dan kehidupan perempuan petani penggarap di lahan PTPN IX, termasuk akses dan kontrol mereka pada pengelolaan lahan tersebut.

Dalam hal ini, menurut Sajogyo (1983) peranan perempuan dapat dianalisis dalam dua cara yaitu: Pertama, dalam status atau kedudukannya sebagai ibu rumah tangga, perempuan melakukan pekerjaan rumah tangga sebagai bagian dari proses reproduksi yaitu suatu pekerjaan yang tidak langsung menghasilkan pendapatan tetapi memungkinkan anggota rumah tangga yang lain untuk melakukan pekerjaan mencari nafkah.

Kedua, pada posisi sebagai pencari nafkah (tambahan atau pokok), perempuan melakukan pekerjaan produktif yang langsung menghasilkan pendapatan. Pekerjaan rumah tangga seperti memasak, mengasuh anak, membersihkan rumah, dan mengambil air sebaiknya diperhitungkan sebagai kegiatan "pekerja" dalam arti kata yang produktif. Pekerjaan ini, meski pun bukan berarti "penghasilan", tetapi mempunyai fungsi memberi dukungan bagi anggota rumah tangga lain "pencari nafkah" untuk memanfaatkan peluang kerja.

Penjelasan ini memberikan dasar analisis untuk melihat perempuan yang bekerja di sektor pertanian, bahwa peran yang mereka lakukan, tidak melulu hanya dilihat sebagai peran domestik belaka, tetapi juga peran publik yang berorientasi pada peningkatan kesejahteraan keluarga.

Partisipasi perempuan pada bidang-bidang tertentu termasuk dalam pembangunan masih rendah jika dibandingkan dengan laki-laki. Keberhasilan partisipasi masyarakat dalam pembangunan seringkali hanya dilihat dari partisipasi masyarakat secara umum tetapi jika dilihat 
dari perspektif gender belum tentu berhasil (Tarigan,H,dkk, 2010:21).

Di sektor pertanian, keterlibatan perempuan disebabkan karena perempuan memilikirasatanggungjawabdankepemilikan yang besar terhadap keluarga. Perempuan lebih responsif dalam mengatasi persoalan pangan keluarga dan upaya peningkatan pendapatan dibandingkan laki-laki, sehingga kesempatan bekerja di luar rumah diperoleh oleh para petani perempuan. Akan tetapi, bekerja di luar rumah tampaknya lebih karena persoalan desakan ekonomi. Hanya saja, sekalipun perempuan bekerja di lahan pertanian, tetap saja dipandang sebagai ibu rumah tangga, bukan sebagai petani. Hal ini tampak pada system pengupahan yang memberikan upah rendah bagi perempuan. Semua proses marginalisasi yang terjadi pada kaum perempuan, bukanlah berarti perempuan bodoh untuk mengubah nilai. Perempuan juga mampu jadi perubah nilai kemasyarakatan (Farmia,2006:37-38).

Aktivitas, akses, dan kontrol perempuan pekerja sektor pertanian dalam tulisan ini dianalisis dengan mempergunakan teknik analisis Harvard yang sering diistilahkan sebagai GFA (Gender Framework Analysis) (Handayani, dkk, 2006:160-124). GFA ini digunakan untuk melihat suatu profil gender dari suatu kelompok sosial dan peran gender dalam proyek pembangunan. Melalui Teknik analisis Harvard atau Gender Framework Analysis ini (Qoriah,S.N,et al, 2008:212), peran perempuan dapat dilihat dalam 3 (tiga) kategori analisis, yakni: Pertama, profil aktivitas, yakni melihat interaksi antara perempuan dengan proyekproyek pembangunan sekaligus melihat aktivitas berdasarkan pada pembagian kerja gender, sehingga memungkinkan untuk dilakukan pengelompokan menurut umur, etnis, kelas sosial tertentu, dimana dan kapan tugas-tugas tersebut dilakukan. Aktivitas dikelompokkan menjadi tiga, yaitu produktif, reproduktif/rumah tangga, dan sosial-politik-keagamaan.

Kedua, profil akses untuk melihat kesempatan yang dimiliki perempuan untuk mengelola sumber daya alam. Hal ini juga dipakai untuk melihat siapa yang mempunyai akses terhadap sumberdaya produktif, termasuk sumberdaya alam seperti tanah, hutan, peralatan, pekerja, kapital atau kredit, pendidikan atau pelatihan.

Ketiga, profil kontrol untuk melihat kewenangan yang dimiliki perempuan dalam mengambil keputusan dan menggunakan hasil sumberdaya. Di sini, sumber daya diartikan sebagai sumberdaya yang diperlukan untuk melakukan tugas-tugas tersebut, yakni sumberdaya yang berdimensi ekonomi, politis, sosial, dan waktu.

\section{METODE PENELITIAN}

Tulisan ini berdasar pada hasil penelitian yang menggunakan metode kualitatif. Metode kualitatif merupakan prosedur penelitian yang menghasilkan data deskriptif berupa kata-kata tertulis atau lisan dari orang-orang dan perilaku yang dapat diamati. Metode kualitatif deskriptif digunakan untuk mempelajari dan menerangkan kasus secara natural.

Penelitian ini dilaksanakan di Dusun Slamet, Desa Meteseh, Kecamatan Boja, Kabupaten Kendal. Di Desa Meteseh, banyak penduduk yang menggarap lahan perkebunan karet PTPN IX, khususnya unit kerja Kebun Merbuh, baik yang secara administratif berasa di Desa Meteseh, maupun wilayah diluar administrasi Desa Meteseh, tetapi berbatasan langsung dengan Desa Meteseh.

Sumber data penelitian kualitatif berupa kata-kata, tindakan dan data tambahan seperti dokumen dan lain sebagainya. Data yang digunakan dalam penelitian ini yaitu data primer dan data sekunder. Data primer merupakan data yang didapat langsung dari pengamatan dan wawancara terhadap subjek penelitian yakni Perempuan yang menjadi petani penggarap pada lahan PTPN IX di Desa Meteseh dan informan yang merupakan individu-individu tertentu yang diwawancarai untuk keperluan penggalian informasi yang diperlukan dalam penelitian. Informan dipilih berdasarkan status dan posisinya dalam masyarakat, yang mengetahui persis tentang permasalahan yang diajukan, antara lain: aparat 
pemerintahan desa, tokoh masyarakat, dan warga masyarakat dewasa. Sedangkan data sekunder digunakan untuk melengkapi data primer. Data sekunder yang digunakan dalam penelitian ini berupa buku-buku yang relevan dengan focus masalah. Selain itu, juga mempergunakan dokumen monografi Desa Meteseh. Data primer didapatkan melalui metode observasi dan wawancara mendalam, sedangkan data sekunder dilakukan dengan metode wawancara dan studi pustaka yang luas.

\section{HASIL DAN PEMBAHASAN}

Desa Meteseh merupakan salah satu desa yang secara administratif berada di Kabupaten Kendal. Secara topografis, Kabupaten Kendal dibagi atas 3 (tiga) jenis wilayah, yakni wilayah pegunungan yang berada di bagian selatan, wilayah perbukitan yang berada di tengah, dan wilayah dataran rendah yang berada di sebelah utara. Dari ketiga jenis topografi tersebut, Desa Meteseh termasuk dalam kategori wilayah perbukitan. Dengan topografi perbukitan ini, maka sejak masa kolonial hingga sekarang, wilayah Desa Meteseh menjadi wilayah yang cukup potensial bagi bisnis perkebunan. Kopi dan karet adalah dua jenis tanaman perkebunan yang pernah digalakkan di wilayah ini, baik yang dikelola oleh perusahaan perkebunan swasta, maupun perusahaan perkebunan negara melalui PTPN IX. Sebagai desa yang dikelilingi oleh lahan perkebunan, baik milik negara maupun milik perusahaan swasta, serta lahan hutan yang dimiliki oleh PERHUTANI, maka Desa Meteseh memiliki kekayaan alam yang cukup potensial. Namun demikian, lahan tersebut tidak banyak dikelola oleh warga sebab pengelolaannya harus berdasarkan izin dari pihak perusahaan negara atau swasta tersebut. Adapun batas-batas Desa Meteseh adalah: Sebelah utara berbatasan dengan Desa Trisobo, sebelah selatan berbatasan dengan Desa Boja dan Desa Cangkiran, sebelah timur berbatasan dengan Kelurahan Jatisari, Kota Semarang, dan sebelah barat berbatasan dengan Desa Merbuh.

Desa Meteseh memiliki 8 dusun, di antaranya adalah Dusun Slamet yang saat ini warganya banyak menggarap lahan PTPN IX untuk ditanami tanaman tumpang sari. Lokasi tanaman karet milik PTPN IX sebenarnya berada di Kecamatan Singorojo, tetapi warga Dusun Slamet yang diberikan akses penggarapan sebab secara geografis, wilayahnya lebih dekat dengan lokasi tanaman karet tersebut. Dusun Slamet memiliki 4 (empat) RT dengan penduduk berkisar 650 jiwa yang terbagi atas $170 \mathrm{KK}$.

Dibukanya akses penggarapan warga pada lahan PTPN IX di dasarkan pada adanya PKBL (Program Kemitraan Bina Lingkungan) yang berlaku bagi setiap BUMN, semacam (Corporate Social Responsibilty) bagi perusahaan swasta. Program ini dimaksudkan agar perusahaan memiliki tanggung jawab sosial dan kontribusi bagi peningkatan kesejahteraan masyarakat setempat. PKBL di PTPN IX dilaksanakan dalam dua bentuk yakni secara langsung dengan mengangkat warga desa setempat dalam perekrutan karyawan, penyadap, dan mandor. Mereka inilah yang diberikan akses untuk menanam tanaman tumpang sari di sela-sela tanaman karet yang baru direplanting. Sedangkan bagi warga desa yang tidak terdaftar sebagai karyawan, penyadap, dan mandor di PTPN IX, maka pemberdayaannya dilakukan dengan mengikuti pola PKBL yang diselenggarakan oleh BUMN pada umumnya, misalnya pemberian beasiswa bagi masyarakat setempat dari SD hingga Perguruan Tinggi.

Saat ini, jumlah orang yang bekerja sebagai penyadap tetap sekitar kurang lebih 600 orang dan penyadap/pekerja musiman sekitar $1600-1800$ orang /tahun. Untuk penyadap/pekerja musiman ini, sistem penggajiannya didasarkan atas prestasi kerja, bukan harian atau bulanan. Khusus untuk Dusun Slamet Desa Meteseh, dari 170 jumlah Kepala Keluarga, ada kurang lebih 50 KK yang menjadi petani penggarap di lahan PTPN IX. Lahan garapan warga Dusun Slamet sebenarnya secara administratif masuk dalam wilayah Kecamatan Singorojo, tetapi karena masyarakat yang paling dekat dari lahan tersebut adalah warga Dusun Slamet, Desa Meteseh, Kecamatan 
Boja, maka pihak PTPN IX memberikan kesempatan kepada warga Dusun Slamet untuk menggarapnya. Hal ini dimaksudkan agar masyarakat juga dapat mengawasi keamanan tanaman karet.

Ini adalah langkah persuasi Mbak, agar sama-sama diuntungkan, masyarakat bisa meningkat ekonominya, PTP juga terjaga keamanannya (Suparyo, 35 tahun, Petugas Keamanan Pabrik PTPN IX, warga Dusun Slamet. Catatan: PTP yang disebutkan diatas maksudnya adalah PTPN IX).

Lahan PTPN IX yang saat ini sedang digarap oleh masyarakat untuk tanaman tumpang sari seluas kurang lebih 200 ha. Khusus untuk Dusun Slamet, warga masyarakat saat ini memanfaatkan lahan PTPN IX sebagai lahan garapan seluas kurang lebih 75 ha. Masing-masing Kepala Keluarga menggarap 2 plantiran, dengan luas 1 plantir adalah $5 \times 100 \mathrm{~m}$. Proses penggarapan dimulai sejak karet ditebang sampai akan ditanami kembali dengan tanaman karet yang baru. Setelah ditanami, maka masyarakat dapat pula menanaminya dengan tanaman tumpang sari berupa jagung, kacang tanah, dan padi gogo. Tanaman tumpang sari ini hanya bisa ditanami jika tanaman karet masih kecil atau istilahnya TBM (Tanaman Belum Menghasilkan, yakni TBM tahun pertama hingga keempat. Ketika tanaman karet sudah besar, atau sudah menncapai TBM tahun kelima dan keenam, yakni masa penyadapan, maka tumpang sari di karet sudah harus dihentikan sebab akan mengurangi unsur hara tanah. Bagi masyarakat juga demikian, sebab ketika pohon karet mulai besar dan memiliki daun yang rimbun, maka tanaman tumpang sari mereka juga tidak akan tumbuh dengan baik.

Pada tanaman tumpang sari ini, ada perjanjian antara pekerja dan perusahaan secara tertulis yang diketahui oleh kepala desa dan adminstratur. Semua hasil tumpang sari tersebut adalah milik warga, dan perusahaan tidak meminta. Setiap Kepala Keluarga (KK) bisa menggarap lahan karet untuk tumpang sari seluas 1 plantiran sampai
2 plantiran. Dari TBM tahun pertama ke TBM tahun kedua, masyarakat harus memperbaharui perjanjiannya. Dengan model pemberian akses ke warga setempat untuk menggarap lahan PTPN IX ini, maka perekonomian di Dusun Slamet dan Desa Meteseh pada umumnya dirasakan warga semakin meningkat.

Pada dasarnya, pemberian akses garapan di lahan PTPN IX diberikan untuk setiap kepala keluarga, sehingga perempuan sebagai anggota dari keluarga tersebut secara tidak langsung memiliki akses terhadap lahan PTPN IX. Meski demikian, perempuan pada hakikatnya memiliki akses yang sama dengan laki-laki, sebab pemberian lahan garapan diprioriaskan pada penyadap, karyawan, dan buruh PTPN IX. Dalam hal ini, perempuan pun banyak yang menjadi pekerja di PTPN, umumnya sebagai penyadap. Bagi perempuan yang menjadi kepala keluarga, maka akses tersebut diberikan secara langsung, atau dengan kata lain perjanjiannya atas nama perempuan tersebut.

Aktivitas yang dilakukan perempuan di lahan garapan hampir sama dengan aktvitas yang dilakukan oleh laki-laki, yakni disesuaikan dengan kalender musim penggarapan. Dari masa penebangan pohon karet, lahan tersebut sudah bisa ditanami hingga penanaman kembali pohon karet (replanting), hingga karet berumur 3 tahun, atau Tanaman Belum Menghasilkan (TBM) III. Lahan tersebut ditanami kacang tanah dengan masa panen 3 bulan, padigogo dengan masa panen 4 bulan, dan jagung dengan masa panen 4-5 bulan. Pasca replanting, tanamantanaman tumpang sari ini ditanam di selasela tanaman karet dengan jarak antara pohon dan tanaman sekitar 1 meter. Dalam satu bedeng, biasanya ditanami satu jenis tanaman, tetapi terkadang pula ditanami dua jenis tanaman, yakni padi gogo dam jagung atau kacang tanah dan jagung.

Aktivitas perempuan dalam proses pertanian ini dapat dilihat dalam tahapantahapan pengelolaan lahan sebagai berikut:

Lahan)

Masa pra tanam (membersihkan

Pada tahapan pembersihan lahan 
ini, perempuan juga terlibat dengan cara membabat tanaman liar dengan memakai alat yang berbeda dengan laki-laki. Jika lakilaki memakai cangkul, maka perempuan umumnya memakai sabit, pisau atau tanpa memakai alat sama sekali.

Masa tanam meliputi:

Pertama, menabur benih. Pada tahapan ini, laki-laki dan perempuan memiliki peran yang sama dan alat/teknologi pertanian yang sama. Anak laki-laki dan perempuan terkadang dilibatkan untuk membantu orang tua mereka, apabila mereka sedang libur atau tidak sekolah.

Kedua, watun (menyiangi rumput). Seperti pada masa penaburan benih, laki-laki dan perempuan sama-sama terlibat dalam menyiangi rumput liar yang mengganggu tanaman. Alat/teknologi pertanian yang dipergunakan sama, yakni sabit dan parang. Hanya saja, peran perempuan dewasa lebih diutamakan dari pada laki-laki dewasa. Anak laki-laki dan perempuan juga sering dilibatkan apabila mereka memiliki kesempatan.

Ketiga, pemupukan. Pemupukan merupakan tahapan terakhir dari masa tanam, sebab apabila tanaman sudah tumbuh besar, maka tanaman tersebut hanya dikontrol saja. Proses pemupukan ini tidak melibatkan anak-anak, baik laki-laki maupun perempuan. Tetapi hanya melibatkan lakilaki dewasa dan perempuan dewasa. Meski demikian, peran laki-laki sangat diutamakan dalam proses pemupukan ini. Sedangkan untuk kontrol tanaman, laki-laki dan perempuan memiliki peran dan tanggung jawab yang sama.

Masa panen yang meliputi:

Pertama, tahap memanen. Dalam kegiatan memanen, laki-laki dan perempuan memiliki peran dan tanggungjawab yang sama, sedangkan anak laki-laki dan perempuan hanya sekedar membantu orang tua mereka.

Kedua, tahap penjualan hasil panen.Ada dua bentuk dalam penjualan hasil panen. Ada yang dijual sendiri ke bakul (distributor) yang ada di Pasar Boja, ada pula yang langsung dijual ke pedagang seplantiran. Pada bentuk penjualan ke distributor di Pasar Boja, petani penggarap dapat menentukan sendiri berapa banyak yang harus dijual dan berapa banyak yang akan dikonsumsi sendiri. Dalam hal ini, perempuan memiliki andil untuk menentukan hasil panen yang akan dijual dan hasil panen yang akan dikonsumsi sendiri. Sedangkan jika dijual dalam bentuk plantiran, maka tanaman langsung dihargai oleh pedagang seplantiran. Di sini, petani penggarap khususnya perempuan tidak memiliki kewenangan untuk menentukan hasil panen mereka yang ingin dikonsumsi sendiri. Penentuan bentuk penjualan, apakah memakai sistem bakul ataukah sistem plantiran, biasanya diawali dengan pembicaraan antara laki-laki dan perempuan dalam satu rumah tangga, tetapi yang melakukan negosiasi dengan pedagangm biasanya laki-laki.

Sedangkan untuk aktivitas domestik dan reproduksi, maka peran perempuan sangat dominan, sebagaimana terlihat dalam matriks berikut ini:

Dari matriks di atas dapat diketahui bahwa semua sumber daya anggota keluarga dilibatkan dalam aktivitas domestik. Hanya saja peran dan tanggung jawab mereka berbeda. Perempuan dewasa (istri) memiliki peran dan tanggung jawab yang lebih di banding yang lain, sedangkan lakilaki dewasa (suami), laki-laki anak dan perempuan anak hanya sekedar membatu urusan domestik dari perempuan dewasa.

Keberhasilan pengelolaan lahan garapan sesungguhnya tidak lepas dari peran serta perempuan (istri), meski secara yuridis perjanjian penggarapan lahan bukan atas nama mereka. Mereka tidak pernah mempersoalkan tentang faktor yuridis tersebut, sebab hal yang paling penting bagi mereka terletak pada akses penggarapannya. Keberhasilan penggarapan lahan tersebut juga merupakan keberhasilan mereka dalam meningkatkan ekonomi dan kesejahteraan keluarga. Dalam hal penggarapan lahan, akses (peluang atau kesempatan) yang dimiliki perempuan terhadap sumber daya yang mereka miliki tidak jauh berbeda dengan laki-laki. Untuk sumber daya fisik seperti lahan garapan dan kebun (tegalan), laki-laki dan perempuan memiliki peluang 
Tabel 1. Aktivitas Domestik dan Reproduksi

\begin{tabular}{cllllll}
\hline No & Jenis Aktivitas & La & Ld & Pa & Pd & Ket \\
\hline 1 & Memasak & - & - & - & $\sqrt{ }$ & Tugas Pd \\
2 & Mencuci Pakaian & & & $\sqrt{ }$ & $\sqrt{ }$ & Tugas Pd dan Pa \\
3 & Mencuci piring & & & $\sqrt{ }$ & $\sqrt{ }$ & Tugas Pd dan Pa \\
4 & Mengambil kayu api & $\sqrt{ }$ & $\sqrt{ }$ & $\sqrt{ }$ & $\sqrt{ }$ & Tugas semua \\
5 & Mengambil air & - & - & - & - & Air sudah masuk ke rumah melalui kran \\
6 & Mengurus anak & & $\mathrm{B}$ & & $\sqrt{ }$ & Tugas Pd, Ld hanya membantu, misalnya \\
7 & Memandikan anak & & $\mathrm{B}$ & & $\sqrt{ }$ & Tugas Pd, Ld hanya membantu \\
8 & Menyuapi anak & & $\mathrm{B}$ & & $\sqrt{ }$ & Tugas Pd, Ld hanya membantu \\
9 & Menggendong anak & $\mathrm{B}$ & & $\sqrt{ }$ & Tugas Pd, Ld hanya membantu \\
10 & Ke Posyandu & & & $\sqrt{ }$ & Tugas Pd \\
11 & Memperbaiki perkakas & $\sqrt{ }$ & & & Tugas Ld \\
\hline
\end{tabular}

(Catatan: $\mathrm{La}=$ Laki-laki anak, Ld $=$ Laki-laki dewasa, $\mathrm{Pa}=$ Perempuan anak, dan $\mathrm{Pd}=$ Perempuan dewasa)

dan kesempatan yang sama untuk menggarap lahan mereka. Tidak ada perbedaan yang signifikan dalam mengakses sumber daya fisik. Perbedaannya hanya terletak pada teknologi pertanian yang mereka pergunakan untuk mengelola lahan garapan mereka yang biasanya disesuaikan dengan kondisi fisik dan aktivitas pertanian mereka masingmasing. Hanya saja, pada aspek penjualan dan distribusi hasil pertanian, peran laki-laki tampaknya lebih dominan. Hal ini ditandai dengan kurangnya peluang dan kesempatan yang diberikan kepada perempuan untuk secara langsung bernegosiasi dengan pedagang atau pembeli yang akan membeli hasil pertanian mereka.

Akses perempuan terhadap sumber daya fisik dan hasil pertanian, ternyata juga berpengaruh pada kontrol mereka dalam hal tersebut. Kontrol atau kewenangan yang dimiliki perempuan (istri) untuk mengambil keputusan atas penggunaan dan hasil sumberdaya tidak sepenuhnya berada di tangan mereka. Untuk sumber daya fisik seperti lahan garapan dan tegalan, mereka memiliki kewenangan yang sama dalam hal penggarapannya. Kewenangan tersebut terlihat pada keputusan yang diambil bersama untuk penentuan jenis tanaman yang akan mereka tanam dan jenis aktivitas pertanian yang akan mereka kerjakan secara bersama. Hanya saja dalam hal penguasaan dalam hal kepemilikan lahan dan akta perjanjian masih sepenuhnya berada di tangan lakilaki. Begitu pula dalam hal penjualan dan distribusi hasil pertanian, kontrol (kewenangan) yang dimiliki perempuan sangat kecil, sebab peran mereka hanya sekedar diberikan informasi oleh suami mereka terkait dengan pola distribusi dan penjualan mereka. Hasil penjualannya pun sepenuhnya diorientasikan untuk kebutuhan sehari-hari bagi semua anggota keluarga.

Sedangkan pada sumber informasi, akses (peluang dan kesempatan) yang dimiliki perempuan dewasa (istri) hampir sama dengan laki-laki dewasa (lakilaki). Untuk sumber informasi seperti televisi, laki-laki dan perempuan memiliki kesempatan yang sama. Penggunaan media informasi televisi ini, tampaknya cukup dominan dalam keluarga sebab menjadi satu-satunya sumber informasi elektronik di dusun mereka. Jaringan internet belum masuk dan masih sedikit orang yang bisa menggunakannya, sedangkan media radio sudah tidak digunakan oleh masyarakat karena peran dan fungsinya telah tergantikan oleh televisi. Tidak hanya laki-laki dewasa dan perempuan dewasa yang bisa mengakses media ini, tetapi juga anak-anak baik lakilaki maupun perempuan memiliki akses yang sama. Hal ini karena mereka memiliki acara atau program yang berbeda dalam 
waktu yang berbeda, sehingga mereka bisa mengakses televisi dengan cara bergiliran. Hanya saja, kontrol (kewenangan) mereka berbeda. Anak-anak laki-laki atau perempuan biasanya memiliki kewenangan yang lebih lemah dibandingkan dengan orang tua mereka. Begitu pula dengan perempuan dewasa (istri) yang juga memiliki kewenangan yang lemah dibandigkan denag laki-laki (suami). Hal ini terlihat pada saat mereka akan menonton acara televisi yang berbeda tetapi ditayangkan pada saat yang bersamaan. Dalam situasi ini, maka perempuan (istri) lebih banyak yang mengalah.

Pada sumber informasi berupa pendidikan, penyuluhan, pelatihan ataupun brosur, maka orang yang mendapat kewenangan yang lebih besar adalah lakilaki dewasa (suami). Kontrol (kewenangan) mereka yang dominan ini tidak lepas dari anggapan mereka bahwa pengetahuan perempuan (istri) tentang hal-hal yang bersifat publik sangat minim. Bahkan dalam beberapa kesempatan, apabila ada hal yang sesungguhnya diorientasikan untuk perempuan, maka laki-laki (suami) harus mengetahuinya terlebih dahulu. Bagi lakilaki (suami), peran perempuan dalam hal penyuluhan dan brosur hanya sekedar diberi tahu saja, tanpa harus dilibatkan secara langsung. Hal inilah yang mengakibatkan informasi-informasi yang bisa menambah pengetahuan dan skill mereka tidak bisa secara maksimal mereka peroleh. Dengan demikian, maka kontrol (kewenangan) mereka dalam wilayah publik sangat determinan, meskipun peran dan tanggung jawab mereka di wilayah domestik sangat dominan.

Relasi Gender dalam Kehidupan Perempuan Petani Penggarap di Lahan PTPN IX

Aktivitas pertanian tumpang sari yang dilakukan oleh laki-laki dan perempuan di lahan perkebunan karet milik PTPN IX dengan segala akses dan kontrol yang menyertainya, menyebabkan timbulnya relasi gender yang tidak seimbang. Ketidakseimbangan relasi gender ini dapat dilihat dari beberapa aspek. Pertama, pada pola penguasaan lahan pertanian. Hal ini ditandai dengan tidak adanya pelibatan dan pelekatan nama perempuan pada akta perjanjian penggarapan lahan dan sertifikat kebun/tegalan, meski mereka memiliki aktivitas yang sama dengan lakilaki di lahan tersebut. Persoalan ini cukup signifikan meski perempuan (istri) terkadang kurang menyadarinya. Para istri ini kerap menganggap bahwa pelekatan nama mereka dalam akta perjanjian penggarapan pada lahan PTPN IX ataupun pada sertifikat pemilikan kebun/tegalan bukanlah masalah yang harus dipersoalkan sebab yang paling penting adalah akses mereka pada penggarapan lahan tersebut. Jika para suami mereka sudah memilikinya, maka mereka juga sudah bisa mengolahnya secara bersama untuk peningkatan kesejahteraan rumah tangga mereka. Para istri ini tidak pernah membayangkan bahwa pelekatan nama mereka pada akta perjanjian atau sertifikat memiliki arti penting yang lebih dalam yakni apabila terjadi sesuatu dalam kehidupan mereka seperti perceraian atau kematian suami.

Untuk lahan garapan di PTPN IX, masalah yang sering terjadi adalah alih kelola, yakni pengalihan pengelolaan lahan garapan, dari pemilik akta perjanjian ke orang lain. Jika hal tersebut terjadi, maka istri tidak memiliki hak yang penuh untuk menentukan keputusan dan mekanismenya.

Kedua, pada sistem produksi dan distribusi pertanian. Pembagian kerja antara laki-laki dan perempuan dalam masyarakat pertanian, dapat dilihat dalam 3 (tiga) karakteristik, yakni sistem pertanian perempuan, sistem pertanian laki-laki, dan sistem pertanian campuran. Pada masyarakat Asia Tenggara, sistem pertanian campuran umumnya dipraktikkan sebab di sana terdapat produksi pertanian intensif dan tanah yang beririgasi. Pada lahan yang sempit, petani membutuhkan input tenaga kerja keluarga yang banyak agar hasil lahan dapat maksimal. Hal ini mengakibatkan lakilaki dan perempuan seringkali berbagi peran dalam produksi pertanian (Kusujiarti, 2000)

Merujuk pada analisis Boserup di atas, sistem produksi dan distribusi pertanian yang 
dipraktikkan petani di Dusun Slamet, Desa Meteseh ketika mengelola lahan garapan PTPN IX tampaknya mempergunakan sistem pertanian campuran. Luas lahan yang sempit, yakni maksimal 2 plantiran setiap kepala keluarga, membuat petani harus mengalokasikan tenaga kerja yang mereka miliki secara maksimal pada lahan pertanian. Suami dan istri secara bersama mengelola lahan garapan dengan aktivitas yang relatif berbeda. Bahkan anak-anak kerap difungsikan untuk membantu orang tua mereka di lahan garapan. Hal ini dimaksudkan agar lahan garapan yang sempit tersebut dapat memberikan hasil yang maksimal.

Peran dan partisipasi perempuan dalam aktivitas produksi pertanian ini, ternyata tidak berbanding seimbang dengan kewenangan yang mereka miliki. Dalam beberapa hal perempuan dilibatkan pada pengambilan keputusan, tetapi dalam hal yang lain, perempuan justru tidak dilibatkan dalam pengambilan, meskipun keputusan tersebut memiliki kaitan yang cukup siginifikan bagi urusan kesejahteraan rumah tangga. Pelibatan perempuan dalam pengambilan keputusan biasanya hanya seputar jenis tanaman yang akan ditanam sebagai tanaman tumpang sari di sela-sela pohon karet milik PTPN IX. Pelibatan ini pun tidak memiliki dampak yang terlalu jauh sebab jenis tanaman yang akan ditanam biasanya sama dengan tanaman pada tahuntahun sebelumnya, atau jenis tanaman yang ditanam oleh warga dusun pada umumnya. Selain, itu keputusan akhir dalam penentuan jenis tanaman biasanya tetap dimiliki oleh suami.

Sistem distribusi hasil pertanian juga lebih memarginalkan peran perempuan. Istri hanya dilibatkan dalam komunikasi awal untuk menentukan bentuk penjualan hasil pertanian. Selain keputusan akhir ada di tangan suami, distribusi hasil pertanian ini juga tidak memberikan ruang kepada istri untuk bernegosiasi dengan calon pembeli terkait dengan harga yang mereka inginkan. Padahal, hasil penjualan tersebut akan dimanfaatkan untuk keperluan rumah tangga dimana istri yang mengetahui betul kondisi keuangan rumah tangga mereka. Jika demikian, maka posisi istri tidak cukup signifikan dalam menentukan seberapa besar income yang akan masuk untuk kebutuhan rumah tangga mereka.

Ketiga, pada aktivitas level rumah tangga. Aktivitas level rumah tangga biasanya sering dimaknai sebagai aktivitas domestik. Dalam masyarakat pertanian, aktivitas domestik ini banyak diemban oleh perempuan (istri). Seperti pada petani penggarap di Dusun Slamet, curahan waktu yang dimiliki istri untuk mengurus aktivitas rumah tangga lebih banyak dibandingkan dengan laki-laki. Selain karena konstruksi budaya yang masih menepatkan istri pada wilayah dapur, aktivitas rumah tangga yang demikian juga disebabkan oleh adanya anggapan bahwa tugas utama laki-laki adalah di lahan atau kebun, sehingga mereka hanya sekedar membantu istri apabila dibutuhkan. Untuk melihat perbandingan curahan waktu yang dipergunakan antara laki-laki (suami) dan perempuan (istri) setiap hari, maka dapat dilihat dalam tabel berikut ini:

Dari tabel di bawah dapat dilihat bahwa curahan waktu yang harus dikeluarkan oleh istri lebih banyak dibanding dengan curahan waktu yang dilekuarkan oleh suami. Aktivitas domestik yang selalu dibebankan kepada istri tidak mengurangi peran dan beban kerja mereka di lahan garapan. Hal ini menunjukkan bahwa beban ganda (double burden) masih dialami oleh perempuan petani penggarap di lahan PTPN IX.

Menurut (Mahanani, 2003:7), peran ganda perempuan dalam pertanian banyak dipengauhi oleh norma-norma yang dianut dan dipraktikkan pada akhirnya menempatkan perempuan dalam posisi yang lebih rendah dibanding dengan laki-laki. Norma-norma tersebut pada dasarnya adalah pola diskriminasi terhadap perempuan dalam berbagai bentuk karena perbedaan jenis kelamin laki-laki dan perempuan.

Dalam konteks petani penggarap di lahan PTPN IX, selain internalisasi norma-norma ketidakadilan gender tersebut juga dipenguruhi oleh akses dan kontrol perempuan terhadap fasilitas dan layanan publik. 
Tabel 2. Perbandingan Curahan Waktu antara Suami dan Istri

\begin{tabular}{|c|c|c|c|}
\hline NO & WAKTU & AKTIVITAS SUAMI & AKTIVITAS ISTRI \\
\hline 1 & 04.00 & Bangun dan sholat & Bangun dan sholat \\
\hline 2 & $04.30-06.00$ & Santai, menonton TV & Memasak dan beres-beres rumah \\
\hline \multirow[t]{2}{*}{3} & $06.00-08.30$ & Mengantar anak sekolah (jika harus & Membersihkan rumah \\
\hline & & diantar) & Mempersiapkan sarapan \\
\hline 4 & 09.00 & Wolon (Sarapan) & Wolon (Sarapan) \\
\hline 5 & $09.00-12.00$ & Bekerja di lahan garapan & Bekerja di lahan garapan \\
\hline 6 & $12.00-15.00$ & $\begin{array}{l}\text { Mandi, makan siang dan istirahat } \\
\text { siang }\end{array}$ & $\begin{array}{l}\text { Mandi, mencuci, mempersiapkan makan } \\
\text { siang, makan siang, dan istirahat siang }\end{array}$ \\
\hline 7 & $16.00-18.00$ & $\begin{array}{l}\text { Berkumpul atau bercengkrama } \\
\text { dengan bapak-bapak }\end{array}$ & $\begin{array}{l}\text { Masak untuk makan malam (kadang- } \\
\text { kadang menonton TV) }\end{array}$ \\
\hline 8 & $18.00-20.00$ & Makan malam dan menonton TV & Makan malam dan menonton TV \\
\hline 9 & 21.00 & Tidur & Tidur \\
\hline
\end{tabular}

\section{SIMPULAN}

Akses penggarapan untuk pertanian tumpang sari yang dilakukan oleh warga Desa Meteseh Kecamatan Boja pada lahan PTPN IX merupakan bagian dari PKBL (Program Kegiatan Bina Lingkungan) yang diselenggarakan oleh PTPN IX. Dalam program ini, aktivitas pertanian yang dilakukan oleh perempuan tidak lepas dari peran dan posisi mereka sebagai anggota rumah tangga. Hal tersebut disebabkan karena pemberian akses lahan garapan berdasarkan skala rumah tangga, sehingga yang tercatat adalah nama suami mereka sebagai kepala keluarga.

Meski secara formal pola penguasaan lahan garapan berada di tangan suami, tetapi aktivitas pertanian perempuan petani penggarap ini tetap maksimal, yakni sejak masa tanam hingga masa panen. Akses atau kesempatan yang dimiliki perempuan dalam proses produksi dan distribusi pertanian sesungguhnya sangat besar, tetapi hal tersebut tidak disertai dengan kontrol atau pemberian kewenangan yang proporsional bagi perempuan. Para suami kerap menganggap keberadaan istri hanya sebagai pendamping saja tanpa harus dilibatkan dalam menentukan atau memberi keputusan akhir pada aktivitas pertanian yang mereka lakukan. Di samping itu pada level domestik dan publik, istri masih harus mengalami beban ganda (double burden). Hal inilah yang mengakibatkan relasi gender yang terdapat dalam kehidupan petani penggarap pada lahan PTPN IX belum seimbang (equal).

\section{DAFTAR PUSTAKA}

Farmia, A. 2006.'Peran Perempuan Indonesia dalam Pembangunan Pertanian'.Jurnal Ilmu-ilmu Pertanian 2(1).35-41.

Handayani, T . 2006. Konsep dan Teknis Penelitian Gender. Malang: UMM Press.

Kusumijarti dan Ann Ticmayer. 2000. Gender Divison of Labour in Two Javanese Villages.

Mahanani,S. 2003. 'Keadilan Agraria bagi Perempuan Petani- Dalam Konteks Perempuan Petani dan Pengaturan Sumber Agraria (Tanah). Jurnal Wacana 8(2). 1-12.

Qoriah SN, Sumart T . 2008.'Analisis Gender dalam Desa Mandiri Pangan (Studi Kasus: Desa Jambakan, Kecamatan Bayat,Klaten-Jawa Tengah)'. Sodality: Jurnal Transdisiplin Sosiologi, Komunikasi, dan Ekologi Manusia 2(1). 209-234

Sajogyo, Pudjiwati. 1985. Peranan Wanita dalam Perkembangan Masyarakat Desa. Jakarta: Rajawali Press.

Suseno, D dan Suyatna, H. 2007. 'Mewujudkan Kebijakan Pertanian yang Pro-Petani. Jurnal Ilmu Sosial dan Ilmu Politik.' 10.(3). 267-294.

Tarigan, H, Muluk, K, Rocmah, S . 2010. 'Partisipasi Perempuan dalam Perencanaan PNPM Mandiri Perdesaan dalam Meningkatkan Keadilan dan Keseteraan Gender (Studi di Kecamatan Tiga Panah Kabupaten Karo Provinsi Sumatera Utara)', Spirit Publik 7(2). 21-42.

Hardiyanto, F.D. 2010. Fungsi Lembaga Filantropi Dalam Membantu Meningkatkan Kesejahteraan Masyarakat Muslim di Semarang. Jurnal Komunitas. 2(1). 1 - 15 